\title{
TRAVELLING HABITS OF PEOPLE WITH DISABILITIES
}

\author{
Tibor GONDA* \\ University of Pécs, Faculty of Business and Economics, Department of Marketing and Tourism, Pécs, Hungary, e-mail: gonda.tibor@ktk.pte.hu
}

\author{
Citation: Gonda, T. (2021). TRAVELLING HABITS OF PEOPLE WITH DISABILITIES. GeoJournal of Tourism and \\ Geosites, 37(3), 844-850. https://doi.org/10.30892/gtg.37315-717
}

\begin{abstract}
Accessible tourism is an under-researched area in Hungary. Based on the results of a questionnaire survey, the aim of the present study is to present several specific features of the travel demand of people with disabilities, the foremost focus being the examination of the most popular tourism products in the demand of people with disabilities. 268 Hungarians responded to the survey in online and face-to-face contexts. In addition to the Hungarian survey, the article also covers small-sample research results from four other countries (Germany, Italy, Spain and Croatia). The results show that members of the target group reject segregation solutions during their travels, and, as opposed to integration, clearly demand inclusion. Their travel frequency is above average of the entire population, with interests as diverse as those without disabilities. The issue of accessible tourism affects $10 \%$ of the European population, and thus, besides the significance of the issue from a social and societal point of view, this segment cannot be neglected in terms of its market value either. Understanding the expectations of stakeholders and their specific consumer habits is an essential requirement in the development of appropriate tourism supply and in ensuring equal access to services.
\end{abstract}

Key words: accessible tourism, travel frequency, motivation, tourism products

\section{INTRODUCTION}

In developed countries, accessibility is gaining significant ground in the organization of tourism supply. This trend is partly the result of empathy, but it is also due to recognizing the significant business potential of accessibility. In most general terms, accessible tourism means tourism equally accessible to all, including people with disabilities, people with temporary mobility problems, the elderly, families with children, and multi-generational families (Eichhorn and Buhalis, 2011). Accordingly, the main areas of equal access studies correspond to that of the supply side of tourism: accommodation services, catering, tourist attractions, transport, and communication (Of these factors, the studies mostly focus on the accessibility of attractions (Biswas et al., 2020). Based on the results of a questionnaire survey, this study examines the most popular tourism products among people with disabilities and the types of supply they require. Defining the target group of accessible tourism is already an issue. Public opinion often does not include those who, by virtue of their life situations, belong to the target group for a shorter or longer period - for example, pregnant women, people with temporary mobility problems during post-surgical recovery, or the elderly. However, the proportion of the latter is continuously increasing within the total population and many forms of accessibility act as essential need from their perspective. With a broader understanding of and a slightly philosophical approach to this subject, one may also interpret accessibility as the constant concern of a human continuously seeking comfort (Farkas and Petykó, 2019, 2020). Thus, many of us live with a permanent or temporary disability, which could create barriers throughout life, and hinder travel. In fact, accessible tourism is a continuous effort to make all destinations, tourism products and services accessible to all, regardless of physical barrier, disability or age, and whether it is a private or public tourist destination. Although at the level of declaration the urgency of accessibility is no longer questionable, reality shows a different picture. The results of the research carried out within the framework of the international project European Peer Counselor Training in Accessible Tourism Cooperation for innovation and the exchange of good practices' support this assumption. When one intends to map the relationship between people with disabilities and tourism, it must always be borne in mind that guests with varying types of disabilities have different special needs. However, accessibility is vital for them, as in many cases, ignoring their specific needs may make it impossible for them to participate actively in tourism. In Hungary, tourism opportunities, such as habits and needs of people with disabilities, vary considerably in some regards compared to the characteristics of the general population.

\section{LITERATURE REVIEW}

It is not easy to define the term disability as it has many forms. "We can include not only people with reduced mobility, people with visual, hearing, and intellectual impairments, but also those who suffer from other long-term illnesses affecting their quality of life, such as allergies" (Zsarnóczky, 2018:39). According to WHO estimates, one in six people in the world has a disability, and their number is constantly increasing (WHO, 2011). The UN Convention on the Rights of Persons with Disabilities, adopted in 2006 and also published in Hungary, obliges State Parties to ensure accessibility for people with disabilities to sporting, holiday, and tourist venues and services (Act XCII of 2007). Anyone can be affected by this issue at any time. It is enough to think about, for example, the ageing process, but an accident can make someone permanently

\footnotetext{
* Corresponding author
} 
disabled just as well. This is why the current state of ageing societies lends particular gravity to the problem. When reaching a certain age, senior citizens have some special needs, but there could be many other situations that may justify extra needs: for example, those receiving post-traumatic rehabilitation or families with small children (Darcy and Dickson, 2009). The UN World Tourism Organization (UNTWO) is committed to promoting accessible tourism. The World Tourism Day in 2016 was also dedicated to this topic (UNWTO, 2016). Throughout its history, humanity has made strides in the field of accessibility, but only in the second half of the twentieth century did it become a widely recognized social issue. It is now generally accepted that, despite a disability, everyone should be able to enjoy travel in the same way as anyone else, "because enjoying life to the full is a right of all" (Végh, 2005: 31). The European Parliament resolution of 29 October 2015 on new challenges and concepts for the promotion of tourism in Europe emphasizes the importance of developing sustainable, responsible, and accessible tourism; the principle of "tourism for all", and that full accessibility and affordability of tourism are key elements for the su stainability of the sector.

According to the census data of the Hungarian Central Statistical Office, 595,187 disabled persons lived in Hungary in 2011 (Ernszt et al., 2019). However, the number of people affected by accessible tourism can be much higher, as it can be assumed that older people with good general health conditions do not list themselves as disabled, but when using tourism services, they opt to access accessibility features. As tourism becomes a social phenomenon, it is also becoming an important factor in developing the quality of life (Gonda et al., 2019). Fortunately, by now it has become accepted that making travel easier for people with disabilities and providing the necessary physical conditions are not only our human, ethical, moral, and legal duty, but that the tourism of people with disabilities is a key issue in terms of economics too. Even though currently accessibility represents a largely untapped niche in the tourism market, several positive counter examples can also be identified (Buhalis et al., 2012). However, this market segment should not be considered a homogeneous group. They have various special demands on the service, depending on the type and extent of disability. Some obstacles can affect all travelers, while others present an insurmountable problem only to narrower segments (Shaw and Coles, 2004).

The presence of different disabilities creates disparate and specific needs that require unique ideas and solutions. Understanding consumer preferences and attitudes is also necessary for potent supply development for people with disabilities as well (Závodi et al., 2021). Zajadacz presents the needs and creative accessibility solutions designed to meet the demands of people living with disabilities such as blindness and hearing loss (deafness) (Zajadacz, 2015, Zajadacz and Lubarska, 2020). Tourist destinations are at different stages of implementing accessibility: some develop special offers for people with disabilities, while others recognize accessibility as a distinctive feature - recognizing its inherent market potential (Lörincz et al., 2019). The leading European countries of international tourism place significant emphasis on this issue - such as can be seen in the efforts made by Spain (Vila et al., 2015) and Italy (Agovino et al., 2017) in accessible tourism. As for the former socialist countries, Poland concentrates considerable resources to the research of this subject (Zajadacz, 2014, 2019), and it is also clear that there is a growing interest in research into accessible tourism among Hungarian researchers, too (Gonda and Raffay, 2020a). The implementation of accessible tourism is not equal with physical accessibility. The experience afforded by an accessible destination is much more than that: it is the implementation of the principles of independence, equality, and human dignity within the tourist experience. Experiencing the ethos of the place and discovering the geographical space are as important for disabled people as for anyone else.

Therefore, the geographical aspects of the subject should also be elaborated on when researching this topic. It can be seen from the bibliometric analysis of social geography that neither the journals on urban research nor on social geography place adequate emphasis on accessibility or equal access (Csomós, 2018). Important points can be found in the work of Kitchin on themes such as the interpretation of the place (Kitchin, 2009), the validation of the approach to and values of positive geography (Kitchin, 2015), and the dangers faced by and opportunities open to smart communities (Kitchin and Dodge, 2017). By examining these issues, the question of equal access can be examined in the context of spatial use. It is generally accepted that the pleasure of traveling and taking a holiday strengthens a sense of subjective happiness (Csapó et al., 2018, Gonda et al., 2019). This is particularly true for people with disabilities, for whom tourism often brings the potential breaking out of everyday life full of challenges. In many cases, a journey means a celebration for them, and experience helps them establish relationships and facilitate their integration into society (Gálné Kucsák, 2008; Raffay and Gonda, 2020).

Several empirical studies have shown in Hungary that people with disabilities encounter significant problems during travel and are hampered by their disabilities when implementing their travel plans. This is why many people choose the path of "non-travel" (Csapó and Gonda, 2019; Csapó et al., 2019). Scarcely any Hungarian publications deal with accommodation accessibility and the motivations behind the choice of accommodation made by people with disabilities. About half of the people with reduced mobility were prevented from implementing a tourism program due to their disability; this ratio was 75\% in terms of the visually impaired. There is no doubt that a high-quality service provided for guests with disabilities requires empathy and attention from tourism industry participants.

\section{RESEARCH METHODOLOGY}

The professional preparation of the questionnaire survey was carried out in Barcelona in December 2018 with all partners' involvement. It was in Barcelona that the decision was made that the project leading Hungarian partner would carry out the basic research on a sample of 200 people, which would then be compared with national characteristics. For this purpose, each partner undertook to complete 30 questionnaires. The questionnaire survey was started in the spring of 2019 and, due to the low level of willingness to participate, it took five months to complete instead of the originally planned two. It was challenging to reach people with disabilities. Fundamentally, the questionnaire was completed via an online survey program, but in some cases, data were collected personally as well. In this respect, the Hungarian partner was 
very successful: 89 responses were collected with the help of university students during the Accessible Tourism Day held at Orfü at the beginning of September 2019. In fact, 262 questionnaires were completed in Hungary, which is, as far as we know, one of the largest samples in the research of accessible tourism in Hungary so far. These results were then compared and contrasted with what can be regarded as control groups, the results collected by the four other countries, where the numbers of completed questionnaires varied between 22 and 34. Within the current research framework, cross-correlations and the examination of the existence of a significant relationship across respondents' demographic and disability differences and their responses were not planned. First, the largest (Hungarian) sample was analyzed, with the results calculated in percentages. Given the low number of the non-Hungarian sample groups, percentages were not calculated, instead providing raw numbers. A short summary was created, including the obtained results and a workshop study presenting the overall results of the research (Gonda and Raffay, 2021). In total, 47.8\% of Hungarians who completed the questionnaire were male, and $52.2 \%$ female (Table 1). The plurality of Hungarian respondents were between 36 and 50 years of age (47.8\%), so almost half of them belonged to this group. $20.1 \%$ of respondents were aged $18-25,14.2 \%$ between 50 and $65,12.7 \%$ between $26-$ 35 , and $5.2 \%$ were over 66 (Table 2). The collection of such demographic data was complemented by information on economic activity, living arrangements, educational background, and family status (Gonda and Raffay, 2020b).

Table 1. People with disabilities: respondents' gender (Source: author's own editing)

\begin{tabular}{|c|c|c|c|c|c|}
\hline $\begin{array}{c}\text { Gender / } \\
\text { Country }\end{array}$ & Hungarian & Spanish & Italian & German & Croatian \\
\hline Female & 140 & 12 & 13 & 22 & 14 \\
\hline Male & 128 & 9 & 21 & 11 & 18 \\
\hline
\end{tabular}

\section{RESULTS AND DISCUSSION}

\section{Composition and travel frequency of people with disabilities involved in the research}

It was a key aspect of the research to involve people with several types of disabilities. The majority of the respondents' lives are affected by locomotor impairments, as 44\% struggle with this type of disability. The secondhighest number of responses was given in connection with visual impairment, making everyday life more challenging for $20 \%$. This is followed by hearing and intellectual impairments with a ratio of $12 \%$ each, followed by speech disorders (5\%), autism, and Asperger syndrome (3\%). Four percent of respondents said they had multiple disabilities (It was possible for respondents to indicate several answers under the question). In this respect, all research partners have sought diversity and have succeeded in involving people affected by different types of disabilities in the survey. People with locomotion impairment were the largest group everywhere in terms of their number, except in the Croatian sample, where the most significant number of respondents had intellectual disabilities (Figure 1).

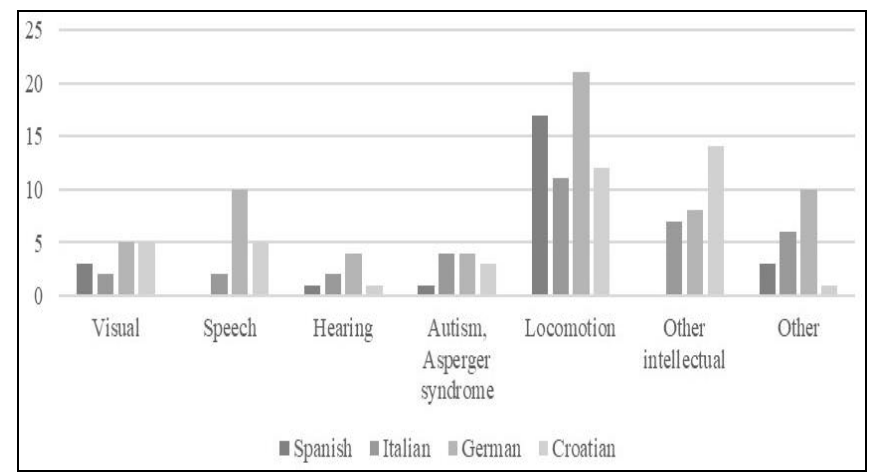

Figure 1. What is the nature of your disability? (Source: Own edit)

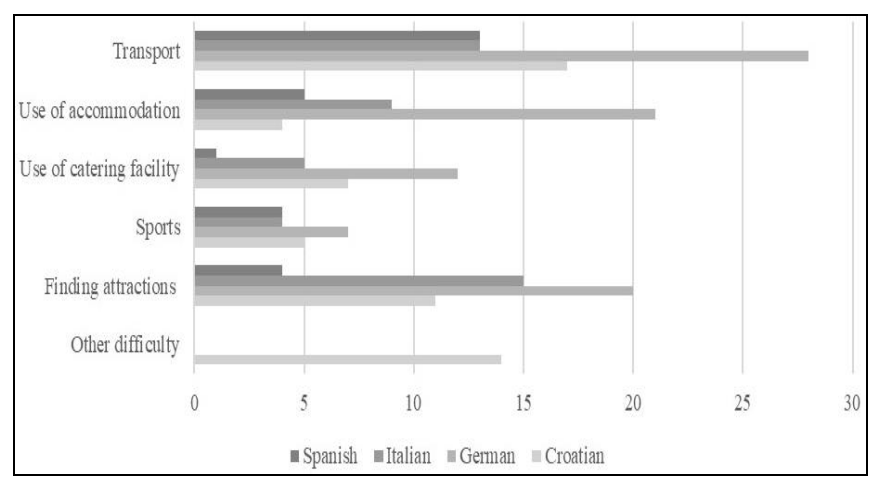

Figure 2. What difficulties do you encounter most often?

Slightly more than two-thirds $(68.7 \%)$ of Hungarian respondents had congenital disabilities, while slightly less than one-third (31.3\%) reported acquired disabilities. Only the Spanish data differ substantially in this regard, where most people were not born with disabilities but acquired them. The main difficulties faced by people with disabilities in Hungary are transport difficulties (30\%), difficulties in the catering industry (20\%), difficulties in accommodation (18\%), difficulties when doing sports (15\%), difficulty in finding tourist attractions (12\%) and communication difficulties (2\%). Only $4 \%$ of respondents said they did not encounter any difficulties in their everyday lives. The other four partners received similar results, as most responses were given to transport difficulties. However, the second largest difficulty for people with disabilities was finding attraction, with accommodation and catering industry mentioned last (Figure 2).

The investigation also covered whether respondents usually travelled abroad or preferred domestic tourism. They were asked to indicate whether they had traveled abroad in the previous five years, and, if so, how many times (Figure 3 ). $36 \%$ of Hungarian respondents replied that they had not traveled abroad in that period of time. Looking at those who had traveled, $13 \%$ had only traveled once, $21 \%$ twice, $6 \%$ three times, and $24 \%$ more than three times.

The next question was intended to reveal whether respondents had traveled domestically in $2018.77 .1 \%$ of respondents did, while $22.9 \%$ did not. Considering those who traveled, $29 \%$ did so once, $23 \%$ twice, $21 \%$ three times, and $27 \%$ three or 
more times. These numbers represent much higher rates than those found in the reports of the Hungarian Central Statistical Office on the travel behavior of the domestic population (KSH 2019) and also than what was previously reported in a representative survey from 2018 (Csapó et al., 2018). In terms of the foreign partners involved in the survey, domestic travel rates were similar. With the following survey item, an attempt was made to discover the reason for non-travelling respondents. The main reason reported was clearly lack of money (25\%), followed by lack of companionship assistance $(15.7 \%)$ and lack of company (10.2\%). Respondents were also afraid that the accessibility features provided during travel would not be in line with promises and their needs $(9.7 \%)$, whereas lack of language skills and the fact that they considered outward and return journey to be cumbersome (9.3 each) were equally dominant factors. Some respondents were afraid of new situations that might come up (7.4\%), others decided to stay at home because of lack of time (6\%), and some were unable to travel $(4.2 \%)$ due to their state of health. A small portion of respondents claimed they could obtain travel experience at home using the internet and technology (2.3\%), while a few referred to transport difficulties $(0.9 \%)$. In a same vein, as seen in the data from Hungary, tourists with disabilities in the partner countries also cited lack of money in this item. This was followed by lack of company, lack of time, lack of language skills or a helping person, with many also fearing that accessibility features would meet neither the promises nor their needs.

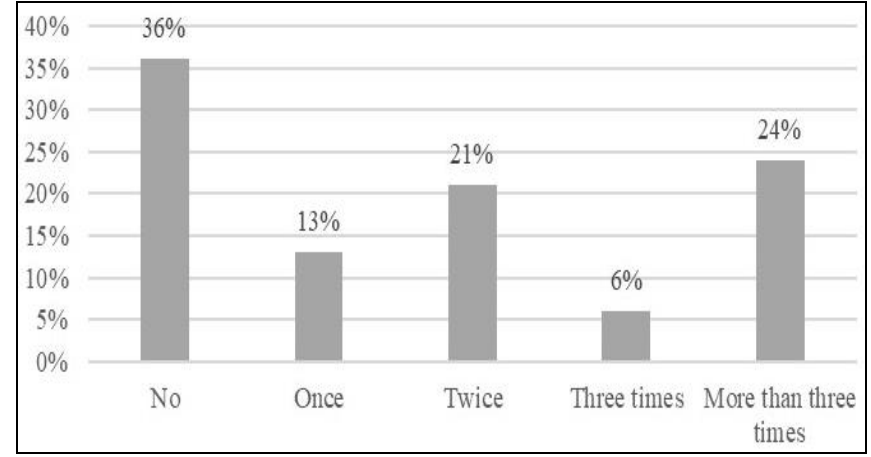

Figure 3. Have you traveled abroad in the last five years? $(\mathrm{n}=254)$ (Source: Own edit)

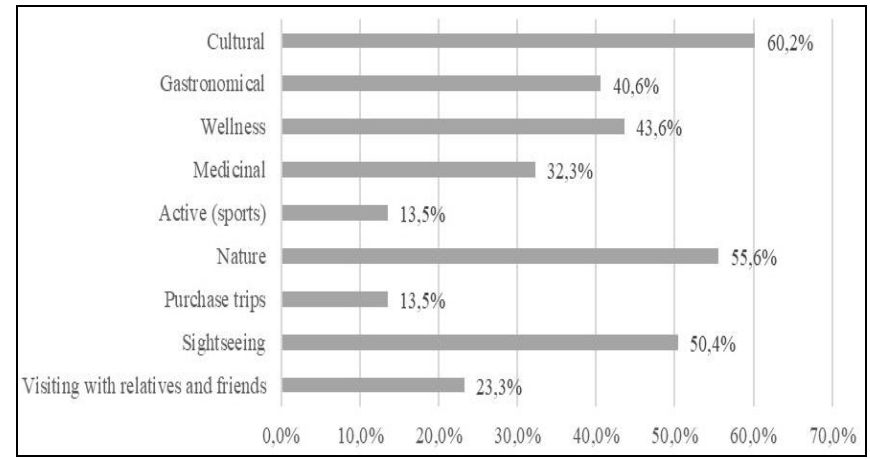

Figure 4. What programs do you prefer while traveling? $(\mathrm{n}=264)$ (Source: Own edit)

\section{Tourism services preferred by people with disabilities}

Another result of the survey was evidence for the importance of making the tourism supply and, by the same token, tourism services, accessible. Only $19.1 \%$ of respondents reported preference for programs designed exclusively for people with disabilities, with another small section (19.8\%) of respondents preferring integrative programs. Almost two-thirds of responses $(61.1 \%)$, however, expressed the position valuing inclusivity: instead of preferring programs designed primarily for people with disabilities, they place a premium on programs available to anyone. It is interesting to note that when asked what programs they preferred, none of the Spanish respondents chose those designed for people with disabilities in mind, instead preferring integrative programs or those not primarily aiming for people with disabilities. As for the other three countries, the least popular tourism programs were those designed for people with disabilities, whereas the most popular were those not primarily tailored for them. When investigating supply, a central aim is to discover the type of motivation and type of tourism product that members of a particular target group are associated with. Respondents were invited to mark as many preferred programs as they saw fit. Cultural $(60.2 \%)$, nature-friendly $(55.6 \%)$ and sightseeing programs $(50.4 \%)$ were the most popular (Figure 4). Many chose wellness (43.6\%) and gastronomical (40.6\%) programs and visiting with relatives and friends (23.3\%). In addition, options chosen included purchase trips and active programs (13.5\% each). Based on this, we can see that the tourism motivation of people with disabilities is wider ranging than the national average, with a pronounced interest in cultural and natural wealth. Sightseeing, cultural and nature programs were most popular among the Spanish and Germans. As for the Italians, sightseeing and cultural programs were followed by a tie of gastronomical and wellness programs, whereas for Croatians, sightseeing and nature-friendly topped the list, followed by a tie of cultural and gastronomical programs (Figure 5).

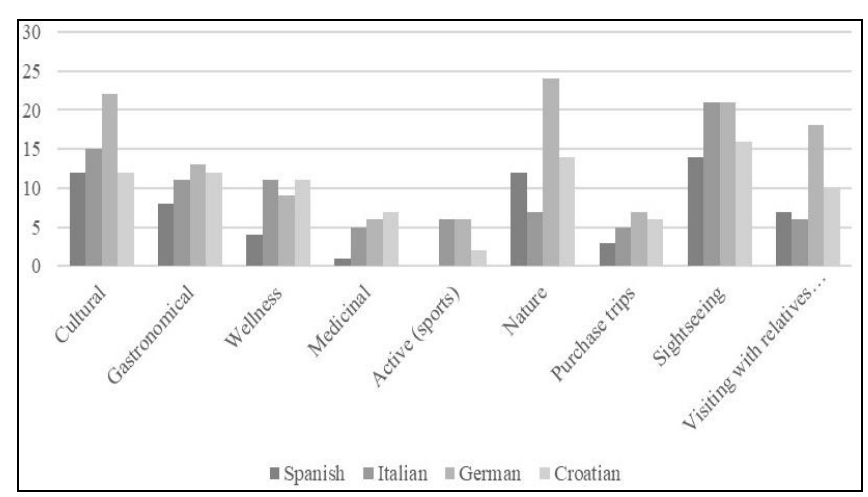

Figure 5. What programs do you prefer while traveling? (Source: Own edit)

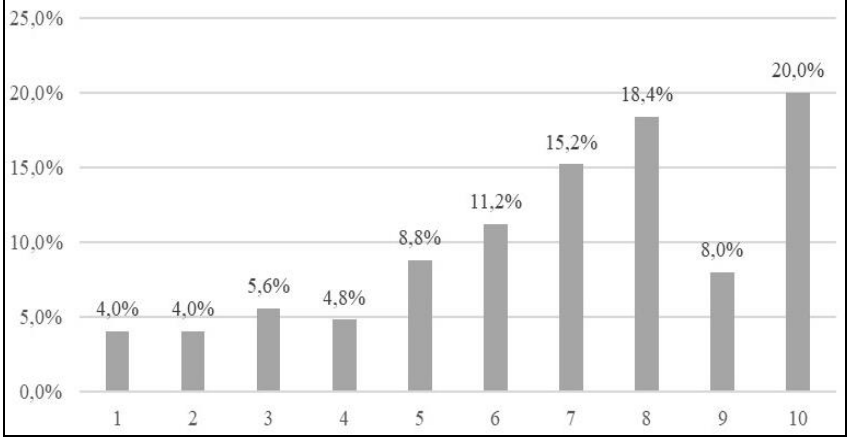

Figure 6. Extreme sports and activities would attract people with disabilities if proper technical support and attendant services were available $(\mathrm{n}=250)$ (Source: Own edit) 
It was not by accident that respondents were also asked about their interest in extreme sports. Although it may appear to some that pursuing extreme sports and disability are mutually exclusive, with proper technical support and the provision of attendants, trying out such activities would attract people with disabilities to a degree higher than the national average. On a scale of 1 to 10, where 1 meant complete disagreement and 10 complete agreement, the majority chose values representing various levels of agreement, with $20 \%$ choosing complete agreement (Figure 6). Responses from the four other countries to the item about extreme sports and activities were similar, with the valued of 10 and 7 chosen by many, although each degree of agreement received responses, showing deviation among respondents (Figure 7).

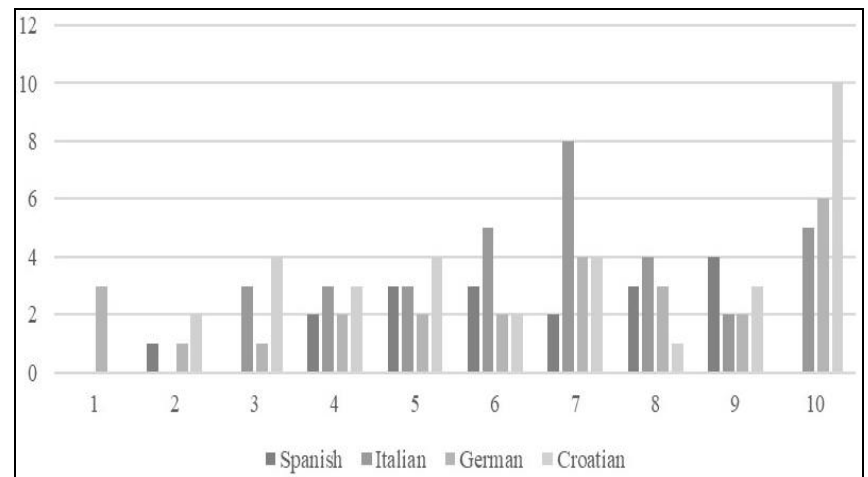

Figure 7. Extreme sports and activities would attract people with disabilities if there was technical and attendant support

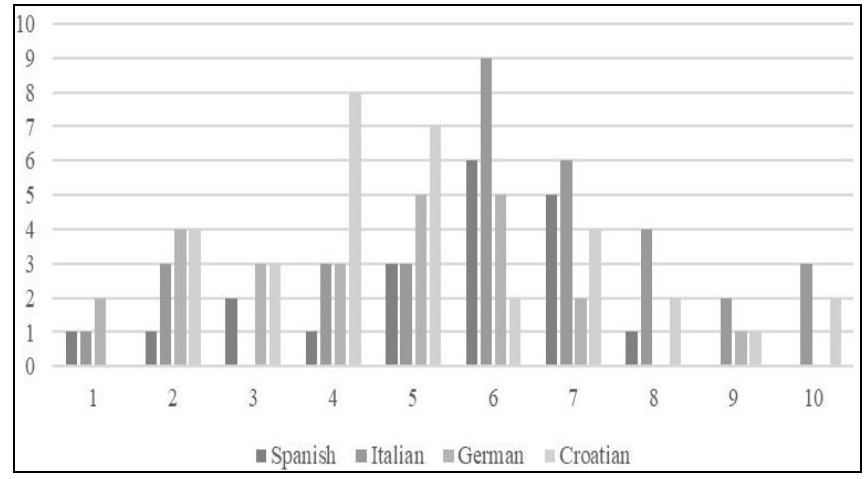

Figure 9. Tourism companies provide guests with disabilities with increased preparedness and openness (Source: Own edit)

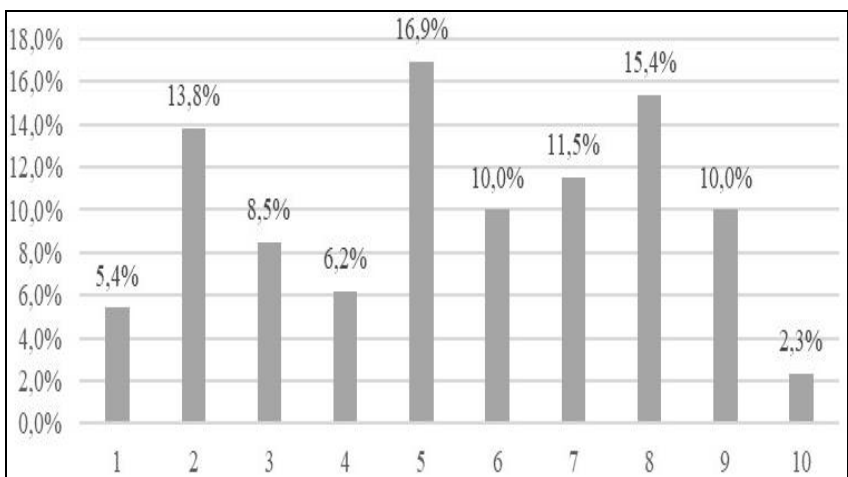

Figure 8. Tourism companies provide guests with disabilities with increased preparedness and openness $(n=260)$ (Source: Own edit)

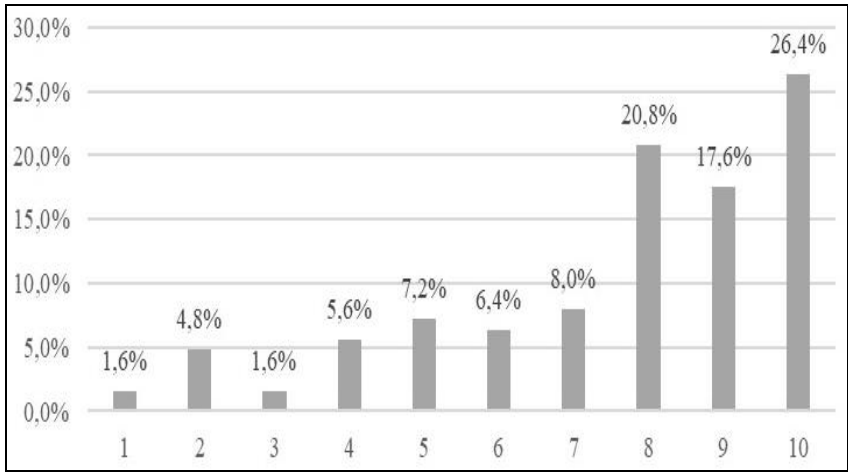

Figure 10. More people in wheelchair would be willing to travel if Hungarian trains and coaches were accessible by wheelchair $(\mathrm{n}=250)$ (Source: Own edit)

\section{Effects of improving convenience of accessible tourism}

Within the attitude analysis, a question was asked about the views target group members held about the state of accessible tourism, inviting respondents to rate their agreements on a scale of 1 to 10 (where 1 indicated complete disagreement and 10 complete agreement). Because tourism service providers are the most important actors who themselves can go a long way toward equal access, the question raised was this: Do tourism companies provide guests with disabilities with increased preparedness and openness? The results appear in Figure 8, which again shows a relatively high degree of deviation across responses, as this item was not met with total agreement. The convenient medium value was chosen by the plurality of respondents $(16.9 \%)$, followed by the values of $8(15.4 \%)$ and $2(13.8 \%)$. Agreements and disagreements were roughly equally present, with the least responses registered for complete agreement, indicating a need for service providers to improve in terms of preparedness and openness. Figure 9, similarly to results for the previous statement, shows no evidence for agreement: responses had a wide range, as also seen in the Hungarian data. The highest values ranged between 4 and 7 . As the relationship between tourism and mobility opportunities afforded by ways of transport is obvious, a specific item was included in the survey about making community transport accessible. The statement was as follows: More people in wheelchairs would be willing to travel if Hungarian community transport were accessible by wheelchair. This item elicited overwhelming agreement, with the majority (nearly two-thirds of respondents) choosing the three highest values ( 8 to 10). There was a much lower percentage of those disagreeing. As for the other four counties, over $90 \%$ of respondents also showed agreement with this statement, with values over the medium range. From all four countries, it was for complete agreement (value 10) that the plurality of choices was registered in the survey. Individual mobility is also stimulated by the presence of accessible tourist trails. Unfortunately, this infrastructure is underdeveloped, although bike lanes, whose development in Hungary is brisk, can be used by people in wheelchairs as well. We have found evidence for such need among people with disabilities in the responses to the item about their views on willingness to hike if at least suburban recreational parks in Hungary had tourist trails accessible by wheelchair. The same way as in the previous item, respondents mostly agreed with the statement as over $60 \%$ voted for the three highest values ( 8 to 10), with the lower values receiving negligible and sporadic support (see Figure 11). We can see a similar spread in the results of the international survey. 


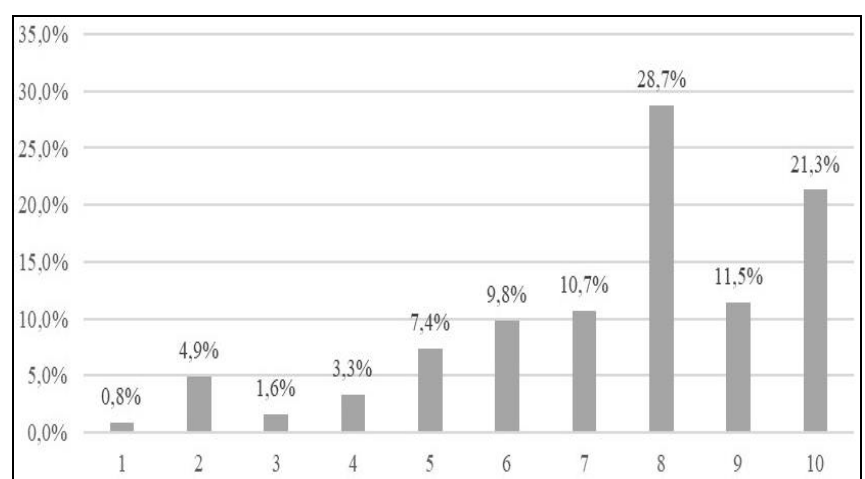

Figure 11. More people in wheelchairs would be willing to hike if at least suburban recreational parks in Hungary had tourist trails accessible by wheelchair $(\mathrm{n}=244)$ (Source: Own edit)

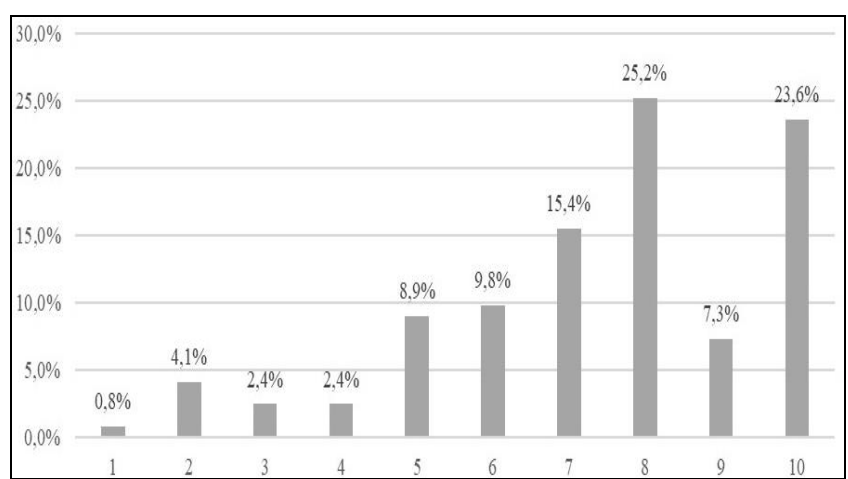

Figure 12. More people would be willing to travel to nature if there was a reliable online database of trips accessible by wheelchair $(n=246)$ (Source: Own edit)

The last item investigated whether a reliable online database of trips accessible by wheelchair would encourage more people to choose a nature travel. The results leave no doubt at all: over half of respondents voted for the top three values, with four-fifths saying more would choose such holidays if there was such a resource. The importance of the internet database was most agreed to by Italians and Croatians, who mostly chose the values of 10 and 8 for this item. The responses from the Spanish and German respondents also showed more agreement, but it was not as strong as in the case of the Italians and Croatians (Figure 13).

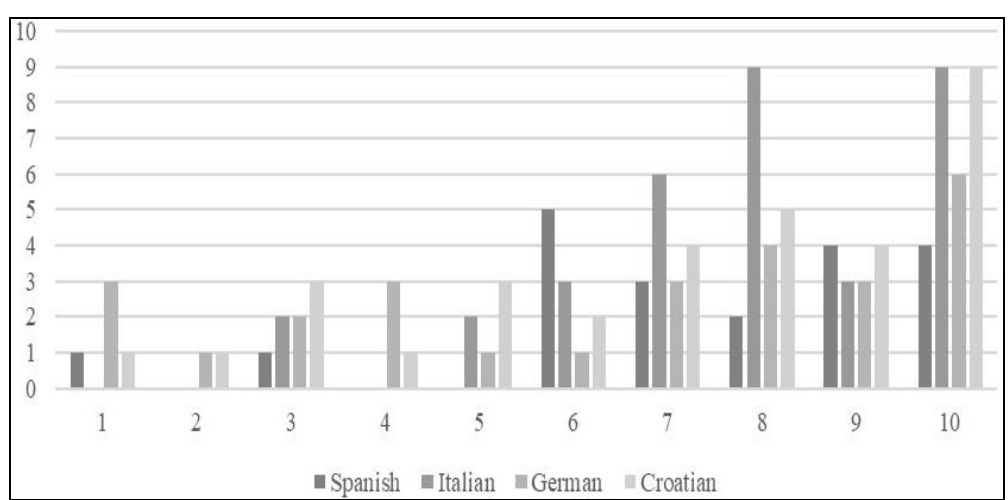

Figure 13. More people would be willing to travel to nature if there was a reliable online collection of trips accessible by wheelchair (Source: Own edit)

\section{CONCLUSION}

The number of people living with disabilities acquired at birth or later in life, permanently or temporarily, is in the billions of the world total population, and this group of special situation and needs is growing in both number and proportion in almost every country. In order to be able to live life to the full, like their non-disabled peers, in addition to ensuring the everyday usability of spaces and buildings, it is necessary, among other things, to be able to travel, to take part in what we may call a "happy journey": in tourism. This is not only an ethical duty of our profession, but also a well-conceived financial interest, because people with disabilities (and often those accompanying them) represent a serious market potential for tourism, which is far from fully exploited.

There are three ways to make travel easier or even more accessible. First, by developing special travel programs and packages for the disabled; by integration within programs designed for people with and without disabilities; and via traditional travel solutions, so that people with disabilities are just as much involved in the travel as their non-disabled counterparts. Unsurprisingly, the latter is by far the most popular among people with disabilities, according to research by Peer Act, the five-country EU project. Apart from a need to comply with the accessibility provisions of international conventions and domestic legislation, this requires sensitizing society, changing attitudes towards people with disabilities, as well as sensitizing and training those working in the travel sector and, of course, tourism facilities and services (travel facilities, accommodation, catering establishments, and attractions) to make it accessible to everyone, not just in the physical sense. The current research has also revealed that among the members of the examined target group, the desire to travel and the frequency of travel are higher than the national average. Driven by their motivation and interests, they look for tourist attractions and services that are similar to those sought by the majority. It has also been confirmed that if physical accessibility improved significantly in a number of areas (public transport, access to extreme sports, accessible tourist routes), demand would increase exponentially. Empirical research has yielded useful and gap-filling knowledge about the travel motivations of people with disabilities and the types of tourism products they most care about. As the next vista of the research, it would be useful to explore additional contexts, through which it would also be possible to gauge the scope of the travel habits and motivations of people with different types of disabilities.

\section{REFERENCES}

Agovino, M., Casaccia, M., Garofalo, A., \& Marchesano, K. (2017). Tourism and disability in Italy: Limits and opportunities. Tourism Management Perspectives, 23, 58-67. https://doi.org/10.1016/j.tmp.2017.05.001

Biswas, C., Omar, H., \& Rashid-Radha, J.Z.R.R. (2020). The impact of tourist attractions and accessibility on tourists' satisfaction: The moderating role of tourists' age. GeoJournal of Tourism and Geosites, 32(4), 1202-1208. https://doi.org/10.30892/gtg.32402-558

Buhalis, D., Darcy, S., \& Ambrose, I. (2012). Best Practice in Accessible Tourism: Inclusion, Disability, Ageing Population and Tourism. Channel View Publications, Bristol/Buffalo/Toronto. 
Csapó, J., Gerdesics, V., Gonda, T., Raffay, Z., \& Törőcsik, M. (2018). Turizmus: a magyar lakosság turizmussal kapcsolatos beállitódása generációs szemléletü vizsgálattal - országos reprezentativ személyes $(n=2001)$ és online $(n=1085)$ megkérdezés, fókuszcsoportos viták eredményei. [Tourism: Investigating the tourism attitudes of the Hungarian population within a generational framework - The results of a national representative survey ( $n=2001$ personal, $n=1085$ online) and focus group debates.] Pécs, Hungary: PTE KTK (2018), 115.

Csapó, J., \& Gonda, T. (2019). A hazai lakosság utazási motivációinak és szokásainak elemzése az aktív turizmus és a fizikai aktivitás tekintetében. [Tourism motivations and habits of the Hungarian population in terms of active tourism and physical activity.] Turisztikai és Vidékfejlesztési Tanulmányok, 4(4), 57-70, 14. https://doi.org/10.15170/TVT.2019.04.04.06

Csapó, J., Töröcsik, M., \& Nagy, Á. (2019). Nemturizmus és életstílus összefüggések. [Connections between non-tourism and lifestyle.] Turisztikai és Vidékfejlesztési Tanulmányok, 4(2), 5-18, 14. https://doi.org/10.15170/TVT.2019.04.02.01

Csomós, G. (2018). Rendíthetetlen-e az angolszász hegemónia a nemzetközi társadalomföldrajzi és városkutatási folyóiratokban: Egy bibliometriai elemzés tanulságai. [Is the Anglo-Saxon hegemony of international social geography and urban research journals unshakable? Results of a bibliometric analysis]. In: Modern Geográfia, 2018(1), 1-18.

Darcy, S., \& Dickson, T.J. (2009). A whole-of-life approach to tourism: The case for accessible tourism experiences. Journal of Hospitality and Tourism Management, 16, 32-44.

Eichhorn, V., \& Buhalis, D. (2011). Accessibility: A Key objective for the tourism industry. In: Budalis, D., \& Darcy, S. (Eds.) Accessible Tourism: Concepts and Issues, 46-61. Bristol: Channel View Publications. https://doi.org/10.21832/9781845411626-006

Ernszt, I., Tóth-Kaszás, N., Péter, E., \& Keller, K. (2019). „Amikor a vándorbot színe fehér, az utazó kerekesszékben ül” - Az akadálymentes turizmus egyes kérdéseiröl. [When the walking staff is white, the tourist is in a wheelchair: Issues in accessible tourism.] Turisztikai és Vidékfejlesztési Tanulmányok, 4(3), 77-91. https://doi.org/10.15170/TVT.2019.04.03.06

Farkas, J., \& Petykó, C. (2019). Utazás az akadálymentesség, a fogyatékosság és a fenntarthatóság multidiszciplináris és bölcseleti dimenzióiba. [Traversing the multidisciplinary and philosophical dimensions of accessibility, disability, and sustainability.] Turizmus Bulletin, 19(4), 13-22, 10.

Farkas, J., \& Petykó, C. (2020). A fogyatékosság, az akadálymentesség és a mobilitás, mint egzisztenciális alaptulajdonság. [Disability, accessibility, and mobility as foundational existential characteristics]. Turisztikai És Vidékfejlesztési Tanulmányok, 5(4), 43-55, 13. https://10.15170/TVT.2020.05.04.03

Gálné Kucsák, K. (2008). A sötétség vándorai: A látássérültek turizmusának helyzete és esélyei Magyarországon. [Wayfarers of the dark: The current state and chances of the tourism of the visually impaired] Turizmus Bulletin, 12(2), 53-59.

Gonda, T., Nagy, D., \& Raffay, Z. (2019). The impact of tourism on the quality of life and happiness. Interdisciplinary Management Research / Interdisziplinare Managementforschung, 15, 1790-1803, 14.

Gonda, T., \& Raffay, Z. (2020a). Egyedül nem megy- fogyatékkal élők utazási szokásainak vizsgálata egy nemzetközi felmérés eredményeinek tükrében. [It's not going to work all alone: The results of an international survey of the travel habits of people with disabilities]. In: Csapó, J. - Csóka, L. (Eds.): Kreativitás, változás, reziliencia. III. Nemzetközi Turizmusmarketing Konferencia: Tanulmánykötet [Creativity, change, and resilience. 3rd International Conference on Tourism Marketing] Pécs, Hungary: Pécsi Tudományegyetem Közgazdaságtudományi Kar, 154-165, 12.

Gonda, T., \& Raffay, Z. (2020b). Accessible Tourism in some European countries - findings and results of an empirical survey (PeerAcT Project) In: Gonda, Tibor; Schmidtchen, Roger (Eds.) Opportunities and challenges of barrier-free tourism in Hungary: Results and recommendations of a scientific workshop during the conference "European Peer-Counselor Training in Accessible Tourism Peer-AcT" on September 4, Bonn, Germany: Bundesinstitut für Berufsbildung, 157, 23-52, 30.

Gonda, T., \& Raffay, Z. (2021). Turisztikai fogyasztási szokások vizsgálata a fogyatékossággal élők körében. [A study of tourism consumption habits among people with disabilities] UPFBE Working Paper Series, 3.1. PTE KTK.

Kitchin, R. (2009). Space II. In: International Encyclopedia of Human Geography. https://doi.org/10.1016/B978-008044910-4.01126-3

Kitchin, R. (2015). Positivist Geography, In: Approaches in Human Geography, 23-34. Publisher: Sage 2015

Kitchin, R., \& Dodge, M. (2017). The (In)Security of Smart Cities: Vulnerabilities, Risks, Mitigation, and Prevention. In: Journal of Urban Technology, 1-19. https://doi.org/10.1080/10630732.2017.1408002

Lőrincz, K., Lang, L.A., \& Banász, Z. (2019). A Balaton térségi Imázsa a helyi lakosság szemszögéből. [The regional image of Lake Balaton from the perspective of the local population] In: Modern Geográfia, 2019(4), 1-14.

Raffay, Z., \& Gonda, T. (2020). Az akadálymentes turizmus innovatív jó gyakorlata. [Best innovative practices in accessible tourism] Modern Geográfia, 2020(4), 1-14, 14.

Shaw, G., \& Coles, T. (2004). Disability, holiday making and the tourism industry in the UK: a preliminary survey. Tourism Management, 25,397-403.

Végh, Z. (2005). A segítséggel élők turisztikai lehetőségei Magyarországon. [Tourism opportunities of people living with assistance in Hungary.] Turizmus Bulletin, 4, 26-38.

Vila, T.D., Darcy, S., \& González, E.A. (2015). Competing for the disability tourism market - A comparative exploration of the factors of accessible tourism competitiveness in Spain and Australia. Tourism Management, 47, 261-272.

Zajadacz, A. (2014). Accessibility of Tourism Space from a Geographical Perspective. Tourism, 24(1), 45-50.

Zajadacz, A., \& Lubarska, A.(2019). Development of a Catalogue of Criteria for Assessing the Heritage Site. Studia Periegetica, 2(26) https://doi.org/10.26349/st.per.0026.06

Zajadacz, A., \& Lubarska, A. (2020). Sensory gardens as place for outdoor recreation adapted to the needs of people with visual impairments. Studia Periegetica, 2(30) https://doi.org/10.5604/013001.0014.3170

Závodi, B., Szabó, G., \& Alpek, L.B. (2021). Survey of the consumer attitude of tourists visiting south. Transdanubia, Hungary. GeoJournal of Tourism and Geosites, 34(1), 245-250. https://doi.org/10.30892/gtg.34133-644

Zsarnóczky, M. (2018). The Future Challenge of Accessible Tourism in the European Union. Vadyba Journal of Management, 2(33), $39-43$.

***Az Európai Parlament 2015. október 29-i állásfoglalása az európai turizmus előmozdításának új kihívásairól és elképzeléseiről 「European Parliament position paper dated October 29, 2015 on the challenges and conceptions related to the advancement of European tourism] (2014/2241(INI)) www.europarl.europa.eu/doceo/document/TA-8-2015-0391_HU.html?redirect letöltés:2020 02.10.

*** European Commission (2014). Economic Impact and Travel Patterns of Accessible Tourism in Europe. Final Report.

*** Központi Statisztikai Hivatal: http://www.ksh.hu/nepszamlalas/tablak_fogyatekossag

*** UNWTO (2016). Highlights of the 1st UNWTO Conference on Accessible Tourism in Europe (San Marino, 19-20 November 2014)

*** UNWTO (2013). Recommendations on Accessible Tourism. Madrid

*** WHO (2011). World Report on Disability. Summary. Malta

*** 1998. évi XXVI. Törvény [The XXVI Act of 1998] 